\title{
Molecular Analyses of Colletotrichum Species from Almond and Other Fruits
}

\author{
Stanley Freeman, Dror Minz, Edouard Jurkevitch, Marcel Maymon, and Ezra Shabi
}

\begin{abstract}
First, fourth, and fifth authors: Department of Plant Pathology, ARO, The Volcani Center, P.O. Box 6, Bet Dagan 50250, Israel; second author: Department of Soil Sciences, ARO, The Volcani Center, P.O. Box 6, Bet Dagan 50250, Israel; and third author: Department of Plant Pathology and Microbiology, The Hebrew University of Jerusalem, Faculty of Agriculture, Food and Environmental Quality Sciences, Rehovot 76100, Israel.
\end{abstract}

Accepted for publication 9 February 2000.

\begin{abstract}
Freeman, S., Minz, D., Jurkevitch, E., Maymon, M., and Shabi, E. 2000. Molecular analyses of Colletotrichum species from almond and other fruits. Phytopathology 90:608-614.

Isolates of Colletotrichum spp. from almond, avocado, and strawberry from Israel and isolates of the pink subpopulation from almond from the United States were characterized by various molecular methods and compared with morphological identification. Taxon-specific primer analysis grouped the avocado isolates within the species $C$. gloeosporioides and the U.S. almond and Israeli strawberry isolates within the species $C$. acutatum. However, the Israeli almond isolates, previously identified mor-

was distinct and clonal. Sequence analysis of the complete internal transcribed spacer (ITS) region (ITS 1-5.8S-ITS 2) revealed a similarity of between 97.03 and $98.72 \%$ among almond isolates from Israel, $C$. acutatum almond isolates from the United States, and C. acutatum strawberry isolates from Israel. Similarity of the above populations to that of $C$. gloeosporioides of avocado was between 92.42 and $92.86 \%$. DNA sequence analysis of the entire ITS region supported the phylogeny inferred from the ITS 1 tree of 14 different Colletotrichum species. Although morphological criteria indicated that the Israeli isolates from almond are unique, this population was grouped within the $C$. acutatum species according to molecular analyses.
\end{abstract} phologically as $C$. gloeosporioides, reacted with $C$. acutatum-specific primers. Arbitrarily primed polymerase chain reaction and A+T-rich DNA analyses determined that each population from almond and strawberry
Additional keywords: Glomerella, rDNA (ITS 1 to ITS 2) sequence, speciesspecific primers.
The filamentous fungal plant pathogens Glomerella cingulata (Stoneman) Spauld. \& H. Schrenk (anamorph Colletotrichum gloeosporioides (Penz.) Penz. \& Sacc. in Penz.) and C. acutatum Simmonds cause anthracnose diseases on various crops worldwide $(2$, $5,15)$. Almond, avocado, and strawberry anthracnose are major diseases that occur in the United States, Israel, and elsewhere $(3,8,19$, 22) and can be inflicted by single or multiple species of Colletotrichum $(1,4,7,10,14,17)$.

Although almond and avocado crops are cultivated in close proximity in Israel, where anthracnose of both crops caused by Colletotrichum spp. occur, no cross-infection has been evident (9). Likewise, although strawberry infected by $C$. acutatum is cultivated in the same geographic regions and under the same climatic conditions as those of avocado and almond crops in Israel, cross-infection among these crops has not been established (8). Therefore, host specificity within a species of Colletotrichum seems to exist in certain cases. In the past, the causal agent of almond anthracnose in Israel was identified as $C$. gloeosporioides based on morphological characteristics alone, such as size of conidia and colony color (22). Recently, Förster and Adaskaveg (7) have reported that two distinct clonal subpopulations of $C$. acutatum infecting almond exist in California. In general, isolates of the species $C$. gloeosporioides are sensitive to benzamidazole fungicides, such as benomyl, and have optimal growth temperatures ranging from 25 to $28^{\circ} \mathrm{C}$ (4). However, the almond pathogen in Israel is insensitive to benomyl and has a low optimal growth temperature $\left(20\right.$ to $\left.22^{\circ} \mathrm{C}\right)$.

Corresponding author: S. Freeman; E-mail address: freeman@netvision.net.il

Publication no. P-2000-0418-01R

(C) 2000 The American Phytopathological Society
These features are in contrast to the two $C$. acutatum subpopulations (gray and pink) from almond in the United States, which are also insensitive to benomyl but have a higher optimal growth temperature of $25^{\circ} \mathrm{C}$ (7). Previously, it was reported that the pink U.S. population belongs to a single vegetative compatibility group, distinct from that of the Israeli population from almond $(1,9,16)$. Deviation of the Israeli almond isolates from the C. gloeosporioides standards raised a doubt regarding its species identity (10). The implication of species identification has direct impact on control measures, as demonstrated by differential sensitivity of C. gloeosporioides and C. acutatum to benomyl.

Morphotaxonomic criteria, as illustrated by the anthracnose pathogens from almond, are not accurate enough to discriminate between Colletotrichum spp.; therefore, much work has been done recently to determine the genetic complexity of isolates infecting subtropical and tropical fruits. A variety of molecular approaches have been used. The GcpR1 repetitive nuclear DNA element from $C$. lindemuthianum (20) and A+T-rich DNA were used for grouping various isolates of $C$. gloeosporioides from strawberry (11) and for determining that the almond pathogen in Israel belongs to a unique clonal lineage (9). Likewise, by using arbitrarily primed polymerase chain reaction (ap-PCR) analysis, it was demonstrated that DNA from eight U.S. isolates of $C$. acutatum (of the pink subpopulation) causing almond anthracnose were distinct from Israeli isolates (9), also corroborated by Förster and Adaskaveg (7). Random amplified polymorphic DNAs (RAPDs) were also used to demonstrate that the U.S. gray subpopulation of $C$. acutatum from almond is very similar to the Israeli almond population (7). Polymorphisms in ribosomal DNA (rDNA) and sequence data of the internal transcribed spacer (ITS) 1 and 2 regions have been used for differentiation of Colletotrichum spp. $(6,18,23,24)$. Similarly, sequencing of the variable D2 domain from the $5^{\prime}$ end of the large rDNA subunit has been also used for species delimitation in the genus Colletotrichum (15). 
A primary objective of this study was to determine whether various molecular methods would give results consistent with morphotaxonomic descriptors for delimiting species of the genus Colletotrichum from various hosts in general, and almond from the United States and Israel in particular. For this purpose, we used representative isolates of Colletotrichum from almond, avocado, and strawberry in Israel, and from the pink subpopulation of almond in the United States. The isolates were compared by five independent molecular methods: (i) PCR amplification using taxon-specific primers, (ii) ap-PCR amplification of genomic DNA, (iii) A+T-rich DNA patterns associated with the mitochondrial genome, (iv) restriction endonuclease digest analysis of PCR-amplified rDNA, and (v) sequencing of the complete rDNA ITS region (ITS 1-5.8SITS 2). Molecular data were used to determine the relatedness among isolates and the accuracy and reliability of these methods for species designation. Phylogenetic analysis was performed to determine whether the ITS 1 and complete ITS 1 to ITS 2 sequences support previous published data (24). These results were further compared with morphotaxonomic characteristics previously published and those recently reidentified.

\section{MATERIALS AND METHODS}

Fungal cultures and growth conditions. The monoconidial Colletotrichum cultures used in this study included 63 Israeli isolates of C. gloeosporioides from avocado fruit, 57 Israeli isolates of Colletotrichum from almond fruit, 19 U.S. isolates of C. acutatum, all belonging to the pink subpopulation from almond fruit, and 230 Israeli isolates of $C$. acutatum from strawberry (Table 1). The Israeli $C$. gloeosporioides isolates from avocado originated from infected fruit collected from packinghouses, supermarkets, and orchards in Israel during the years 1993 to 1997. The C. acutatum isolates responsible for almond anthracnose in the United States were provided by B. Teviotdale (University of California, Davis). The Israeli almond cultures were isolated during the years 1993 to 1998 from infected fruit from groves situated in northern and southern regions of the country. C. acutatum isolates from strawberry originated from infected plants collected during the years 1995 to 1997 (8).

All fungi were cultured in the dark on modified Mathur's medium (MS; $0.1 \%$ yeast extract, $0.1 \%$ bactopeptone, $1 \%$ sucrose, $0.25 \% \mathrm{MgSO}_{4} \cdot 7 \mathrm{H}_{2} \mathrm{O}, 0.27 \% \mathrm{KH}_{2} \mathrm{PO}_{4}$, and $2 \%$ agar supplemented with $25 \mathrm{mg}$ of ampicillin in 1 liter of sterile distilled water) (26). For DNA extraction, liquid cultures comprising $100 \mathrm{ml}$ of MS devoid of agar in 250-ml Erlenmeyer flasks were inoculated with five mycelial disks derived from colony margins. The cultures were agitated for 5 to 6 days on a rotary shaker at $150 \mathrm{rpm}$ and maintained at $25^{\circ} \mathrm{C}$. Twelve hours before harvesting mycelia, the cultures were fragmented by blending for $10 \mathrm{~s}$ at 24,000 rpm with a tissue homogenizer (Ultra-Turrax T25; Janke \& Kunkel, IKA Labortechnik, Staufen, Germany) under sterile conditions and returned to the shaker. To avoid contamination, the homoginizer was washed in sterile water before blending each culture.

Fungal morphological identification. Colletotrichum isolates from representative almond and avocado isolates were sent to P. F. Cannon at CABI Bioscience (Egham, United Kingdom) for independent identification based on morphological characteristics. The U.S. almond isolate (ALM-US-1B) of the pink subpopulation was identified as $C$. acutatum, Israeli avocado isolates (AVO-38-7C and AVO-39-1C) were identified as C. gloeosporioides, and seven Israeli almond isolates (ALM-IKS-7Q, ALM-KSH-10, ALM-BZR-9A, ALM-KN-17Q, ALM-NRB-30K, ALM-NRB-98-UEF, and ALMNRB-98-NPU) were identified as C. gloeosporioides, although some of these exhibited conidial forms that were intermediate between the two Colletotrichum spp. C. gloeosporioides and C. acutatum (P. F. Cannon, personal communication). Conidia of Israeli Colletotrichum isolates from almond varied in form but were often narrow and tapered toward the base, with a small proportion possessing acute ends, and measured 13 to $22 \mu \mathrm{m}$ in length. Conidia of
C. acutatum from almond (United States) and strawberry (Israel) were elliptic-fusiform, narrow, tapered and acute at both ends, and measured 13 to $20 \mu \mathrm{m}$ in length. Conidia of Israeli C. gloeosporioides isolates from avocado were broader than those of the $C$. acutatum and Israeli almond isolates, cylindrical with obtuse ends, and measured 13 to $24 \mu \mathrm{m}$ in length. All isolates were grown on MS medium for identification.

Isolation and purification of fungal DNA. Mycelia from 100-ml MS liquid cultures were collected by vacuum filtration and lyophilized until dry. DNA was extracted and purified as previously described (11). The DNA was dissolved in $0.5 \mathrm{ml}$ of Tris-EDTA buffer (10 mM Tris-HCl and $1 \mathrm{mM}$ EDTA, $\mathrm{pH}$ 8.0) to an approximate concentration of 200 to $500 \mu \mathrm{g} / \mathrm{ml}$ and diluted to a concentration of 10 to $100 \mathrm{ng} / \mu \mathrm{l}$ for PCR reactions.

PCR amplification. For ap-PCR, primers were derived from minisatellite or repeat sequences as follows: CAGCAGCAGCAGCAG (20), TGTCTGTCTGTCTGTC (11), GACACGACACGACAC (13), and GACAGACAGACAGACA (27). In the text, these primers have been designated $(\mathrm{CAG})_{5},(\mathrm{TGTC})_{4},(\mathrm{GACAC})_{3}$, and $(\mathrm{GACA})_{4}$, respectively. Universal PCR primers were used (ITS 1, TCCGTAGGTGAACCTGCGG and ITS 4, TCCTCCGCTTATTGATATGC) for amplification of the ITS 1 and ITS 2 regions between the small and large nuclear rDNA, including the 5.8S rDNA, as described (28). PCR primers for taxon-specific amplification included the ITS 4 primer coupled with specific primers for $C$. acutatum (CaInt2) (GGGGAAGCCTCTCGCGG) and C. gloeosporioides (CgInt) (GGCCTCCCGCCTCCGGGCGG) (5). PCR reactions were performed in a total volume of $20 \mu \mathrm{l}$, containing 10 to $100 \mathrm{ng}$ of genomic DNA; $50 \mathrm{mM} \mathrm{KCl} ; 10 \mathrm{mM}$ Tris- $\mathrm{HCl} ; 0.2 \mathrm{mM}$ each of dATP, dCTP, dGTP, and dTTP; $1.5 \mathrm{mM} \mathrm{MgCl} 2 ; 1$ unit Taq DNA polymerase (Promega Corp., Madison, WI); and $1 \mu \mathrm{M}$ primer. The reactions were incubated in a PTC-100 thermocycler (MJ Research, Inc., Watertown, MA) starting with 5 min of denaturation at $95^{\circ} \mathrm{C}$. For ap-PCR, this was followed by 30 cycles consisting of $30 \mathrm{~s}$ at $95^{\circ} \mathrm{C}, 30 \mathrm{~s}$ at either $60^{\circ} \mathrm{C}$ (for $(\mathrm{CAG})_{5}$ ) or $48^{\circ} \mathrm{C}$ (for $(\mathrm{GACA})_{4},(\mathrm{GACAC})_{3}$, and $\left.(\mathrm{TGTC})_{4}\right)$, and $1.5 \mathrm{~min}$ at $72^{\circ} \mathrm{C}$. For rDNA amplification, denaturation was followed by 40 cycles consisting of $30 \mathrm{~s}$ at $95^{\circ} \mathrm{C}, 30 \mathrm{~s}$ at $50^{\circ} \mathrm{C}$, and $1.5 \mathrm{~min}$ at $72^{\circ} \mathrm{C}$. Taxon-

TABLE 1. Isolates of Colletotrichum species used in this study

\begin{tabular}{llll}
\hline Species & \multicolumn{1}{c}{ Isolate } & \multicolumn{1}{c}{ Origin } & Host plant \\
\hline C. gloeosporioides & AVO-37-4B & Israel & Avocado \\
C. gloeosporioides & AVO-AS-2 & Israel & Avocado \\
C. gloeosporioides & AVO-47-1 & Israel & Avocado \\
Colletotrichum & ALM-BZR-9A & Southern Israel & Almond \\
Colletotrichum & ALM-GVA-6A & Northern Israel & Almond \\
Colletotrichum & ALM-IKS-7Q & Northern Israel & Almond \\
Colletotrichum & ALM-KN-17Q & Northern Israel & Almond \\
Colletotrichum & ALM-NRB-30K & Southern Israel & Almond \\
Colletotrichum & ALM-KSH-10 & Northern Israel & Almond \\
C. acutatum & ALM-US-1A & California & Almond \\
C. acutatum & ALM-US-1B & California & Almond \\
C. acutatum & ALM-US-2A & California & Almond \\
C. acutatum & ALM-US-3A & California & Almond \\
C. acutatum & ALM-US-4 & California & Almond \\
C. acutatum & ALM-US-6B & California & Almond \\
C. acutatum & ALM-US-7A & California & Almond \\
C. acutatum & TUT-5954 & Israel & Strawberry \\
C. acutatum & TUT-136A & Israel & Strawberry \\
C. acutatum & TUT-137A & Israel & Strawberry \\
\hline a a &
\end{tabular}

a Other representative Israeli avocado isolates were AVO-38-7C, AVO-39-1C, and an additional 54 isolates as described (9).

b Other representative Israeli almond isolates were ALM-GOZ-93, ALM-NRB98-UEF, ALM-NRB-98-NPU, and an additional 52 clonal isolates as described (9)

c Other representative U.S. almond isolates of the pink subpopulation were ALM-US-2B, ALM-US-3B, ALM-US-5A, ALM-US-5B, ALM-US-6A, ALM-US-7B, ALM-US-8A, ALM-US-8B, ALM-US-10A, ALM-US-10B, ALM-US-11A, and ALM-US-12A.

d Additional 138 clonal strawberry isolates from Israel as described (8). 
specific PCR reactions were performed under reaction conditions for primer $(\mathrm{CAG})_{5}$, with $0.5 \mu \mathrm{M}$ ITS 4 primer coupled with either $0.5 \mu \mathrm{M}$ primer $C a \mathrm{Int} 2$ for $C$. acutatum-specific detection or $0.5 \mu \mathrm{M}$ primer $C g$ Int for $C$. gloeosporioides-specific detection. Amplification products were separated in agarose gels $(1.5 \%$, wt/vol; $15 \times$ $10 \mathrm{~cm}$, width $\times$ length) in Tris-acetate-EDTA buffer (21) electrophoresed at $80 \mathrm{~V}$ for $2 \mathrm{~h}$.

A+T-rich DNA analyses. A+T-rich DNA was analyzed by HaeIII digestion of total genomic DNA, which cleaves DNA at GGCC sites. HaeIII digests nuclear DNA to fragments mainly less than $2 \mathrm{~kb}$ in size, whereas A+T-rich sequences are cleaved less frequently $(11,12)$. A+T-rich DNA is partially associated with the mitochondrial genome, although contaminating nuclear A+T-rich DNA may also be present. Procedures used for HaeIII restriction enzyme digestion and agarose gel electrophoresis were similar to those previously described (21).

Restriction enzyme digestion of amplified rDNA and sequencing procedure. PCR-amplified rDNA products from representative isolates of Colletotrichum spp., using the primer pair ITS 1 and ITS 4 (28), resulted in a product of approximately $560 \mathrm{bp}$, which was extracted from agarose gels using the Jetsorb kit (Genomed $\mathrm{GmbH}$, Bad Oeynhausen, Germany). Recovered DNA was digested with the restriction enzymes BamHI, HaeIII, HhaI, HindIII, MspI, PstI, RsaI, StuI, and TaqI and separated on agarose gels.

The Big Dye Terminator DNA sequencing kit (Perkin-Elmer Inc., Branchburg, NJ) was used for determining sequence of the ITS 1 to ITS 2 regions (28). The sequence was determined using an ABI prism 377 DNA sequencer (Applied Biosystem Inc., Foster City, CA) and was performed at the sequencing unit of the Hebrew University of Jerusalem, Israel.

TABLE 2. Internal transcribed spacer 1 sequences of Colletotrichum isolates used in this study

\begin{tabular}{|c|c|c|c|}
\hline Species & Isolate & Host & $\begin{array}{c}\text { EMBL } \\
\text { accession }\end{array}$ \\
\hline C. lindemuthianum & $\mathrm{CLD}^{\mathrm{a}}$ & Phaseolus vulgaris & Z 32987 \\
\hline C. orbiculare & $172.59^{\mathrm{a}}$ & Cucumis sativus & Z 33379 \\
\hline C. fructigenum & $4885^{\mathrm{a}}$ & Acmena smithii & Z 32907 \\
\hline C. acutatum & TUT-5954 ${ }^{\mathrm{b}}$ & Fragaria $\times$ ananassa & AF 207794 \\
\hline C. acutatum & $397^{\mathrm{a}}$ & Fragaiae $\times$ ananassa & Z 32915 \\
\hline C. acutatum & ALM-US-4 ${ }^{\mathrm{b}}$ & Prunus dulcis & AF 207793 \\
\hline C. acutatum & $179^{c}$ & Fragaria $\times$ ananassa & Z 32913 \\
\hline C. acutatum & $602 / 91.326^{\mathrm{a}}$ & Phormium spp. & Z 32924 \\
\hline Colletotrichum & ALM-KSH-10 & Prunus dulcis & AF 207791 \\
\hline C. acutatum & $534 / 90.368^{\mathrm{a}}$ & Ceanothus spp. & Z 32918 \\
\hline C. coccodes & $527.77^{\mathrm{a}}$ & Lycopersicon esculentum & Z 32930 \\
\hline C. dematium & $343673^{a}$ & Piper nigrum & Z 32906 \\
\hline C. musae & $489^{\mathrm{a}}$ & Musa nana & Z 32991 \\
\hline C. kahawae & $319406^{\mathrm{a}}$ & Coffea arabica & Z 32983 \\
\hline C. gloeosporioides & SAS $1^{\mathrm{a}}$ & Citrus paradisi & Z 32945 \\
\hline C. gloeosporioides & $498^{\mathrm{a}}$ & Zizyphus jujuba & Z 32955 \\
\hline C. gloeosporioides & AVO-37-4B ${ }^{b}$ & Persea americana & AF 207792 \\
\hline C. gloeosporioides & $503^{\mathrm{a}}$ & Malus domestica & Z 32959 \\
\hline C. gloeosporioides & SAS $8^{\mathrm{a}}$ & Dioscorea spp. & Z 32963 \\
\hline C. gloeosporioides & $501^{\mathrm{a}}$ & Mangifera indica & Z 32957 \\
\hline C. gloeosporioides & $203^{\mathrm{a}}$ & Aeschynomene virginica & Z 32947 \\
\hline C. gloeosporioides & $561^{\mathrm{a}}$ & Fragaria $\times$ ananassa & Z 32961 \\
\hline C. gloeosporioides & $\mathrm{AV} 3 / 1^{\mathrm{a}}$ & Persea americana & Z 32965 \\
\hline C. gloeosporioides & $\mathrm{G} 201^{\mathrm{a}}$ & Persea americana & Z 32967 \\
\hline C. fuscum & $120^{\mathrm{a}}$ & Digitalis lanata & Z 32900 \\
\hline C. gloeosporioides & $502^{\mathrm{a}}$ & Hevea brasiliensis & Z 32958 \\
\hline C. fragaria & $63-1^{\mathrm{a}}$ & Fragaria $\times$ ananassa & Z 32943 \\
\hline C. gloeosporioides & HM335 & Stylosanthes viscosa & Y 16198 \\
\hline C. graminicola & $\mathrm{DR} 1^{\mathrm{e}}$ & Pоа аппиа & AF 059676 \\
\hline C. trichellum & $84989^{a}$ & Hedera helix & Z 33003 \\
\hline
\end{tabular}

a Isolates sequenced by Sreenivasaprasad et al. (24).

${ }^{b}$ Isolates sequenced in this study.

c Isolate sequenced by Sreenivasaprasad et al. (24) and submitted directly to GenBank.

d Isolates sequenced by Munaut et al. (18).

e EMBL accession no. AF 059676
Phylogenetic analysis. Analyses of ITS sequences were carried out using the program package ARB (25). Alignment of sequences was performed with the implemented ARB automated alignment tool, and alignments were refined manually. Phylogenetic analyses were performed by applying ARB parsimony, distance matrix, and maximum likelihood methods. To determine the robustness of phylogenetic trees, analyses were performed both on the original data set and on a data set from which highly variable positions were removed by use of a $50 \%$ conservation filter for members of the genus Colletotrichum, to reduce potential tree artifacts that may result from multiple base changes. Analysis was conducted on the ITS 1 sequences of the U.S. C. acutatum isolates (ALM-US-1B, ALM-US-4, and ALM-US-6B) from almond, the Israeli isolates (ALM-GVA-6A, ALM-KSH-10, and ALM-NRB-30K) from almond, the Israeli $C$. acutatum isolate (TUT-5954) from strawberry, the Israeli C. gloeosporioides isolate (AVO-37-4B) from avocado, and a number of Colletotrichum isolate sequences retrieved from GenBank (Table 2). In addition, sequences of the entire ITS region consisting of the ITS $1,5.8 \mathrm{~S}$ rRNA, and ITS 2 sequences complemented this analysis. Complete ITS 1 to ITS 2 sequences of the U.S. C. acutatum isolate ALM-US-4 from almond, the Israeli Colletotrichum isolate ALM-KSH-10 from almond, the Israeli $C$. acutatum isolate TUT-5954 from strawberry, and the Israeli $C$. gloeosporioides isolate AVO-37-4B from avocado were submitted to GenBank (Table 2).

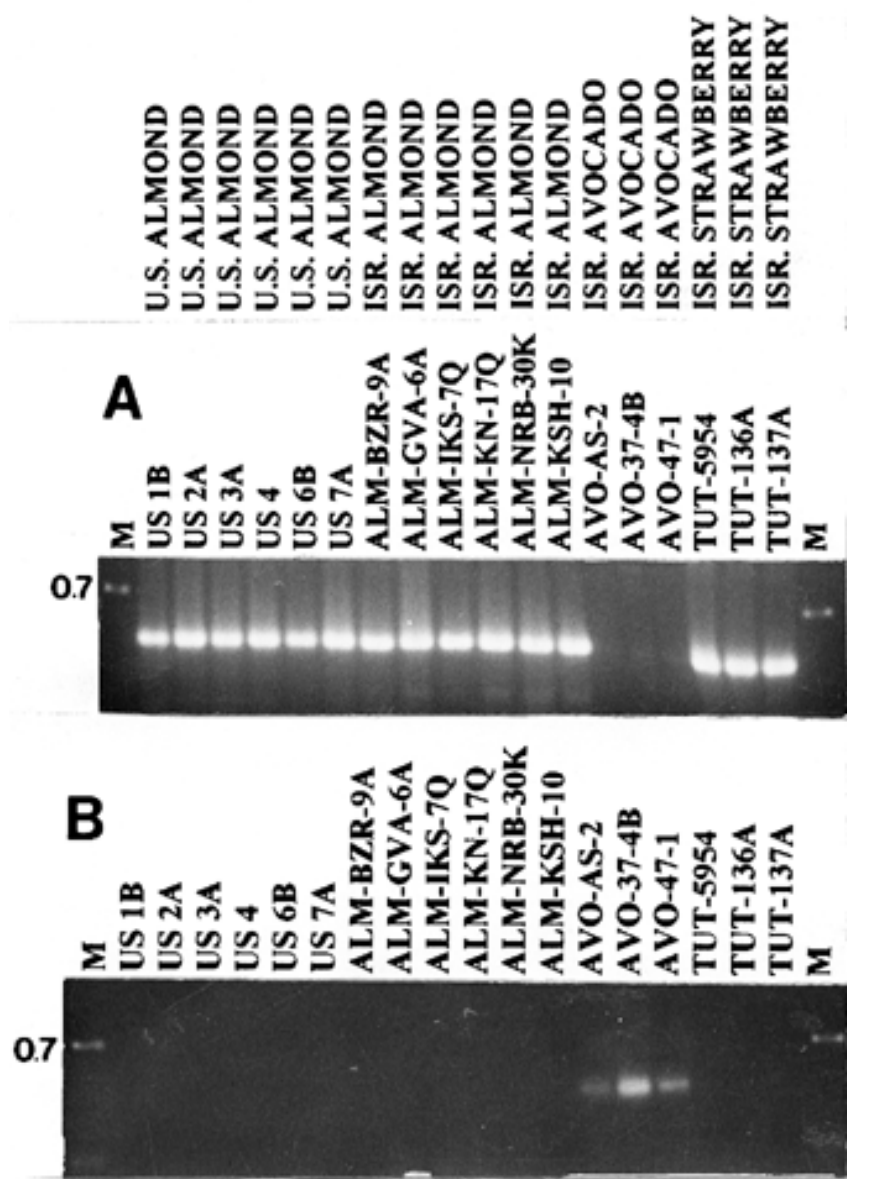

Fig. 1. Taxon-specific A, Colletotrichum acutatum and B, C. gloeosporioides amplification products of genomic DNA from U.S. C. acutatum isolates from almond (ALM-US-1B, ALM-US-2A, ALM-US-3A, ALM-US-4, ALM-US-6B, and ALM-US-7A), Israeli Colletotrichum isolates from almond (ALM-BZR9A, ALM-GVA-6A, ALM-IKS-7Q, ALM-KN-17Q, ALM-NRB-30K, and ALM-KSH-10), Israeli C. gloeosporioides isolates from avocado (AVO-AS-2, AVO-37-4B, and AVO-47-1), and Israeli C. acutatum isolates from strawberry (TUT-5954, TUT-136A, and TUT-137A). Lane M: DNA markers with sizes in kilobases. 


\section{RESULTS}

Taxon-specific primer analysis. DNA from 63 Israeli avocado isolates of $C$. gloeosporioides, 57 Israeli almond isolates, 19 U.S. pink isolates of $C$. acutatum from almond fruit, and 230 Israeli isolates of $C$. acutatum from strawberry were PCR amplified with the taxon-specific primers. Isolates within each population reacted identically and amplified the same size product. Representative isolates were then chosen for presentation of data. DNA of representative Israeli $C$. acutatum isolates from strawberry (TUT-5954, TUT-136A, and TUT-137A), U.S. C. acutatum almond isolates (ALM-US-1B, ALM-US-2A, ALM-US-4, ALM-US-6B, and ALMUS-7A), and Israeli Colletotrichum almond isolates (ALM-BZR9A, ALM-GVA-6A, ALM-IKS-7Q, ALM-KN-17Q, ALM-KSH-10, and ALM-NRB-30K) were PCR amplified with the taxon-specific C. acutatum primers (Fig. 1A). C. gloeosporioides isolates from avocado (AVO-AS-2, AVO-37-4B, and AVO-47-1) were PCR amplified with the taxon-specific C. gloeosporioides primers (Fig. 1B).

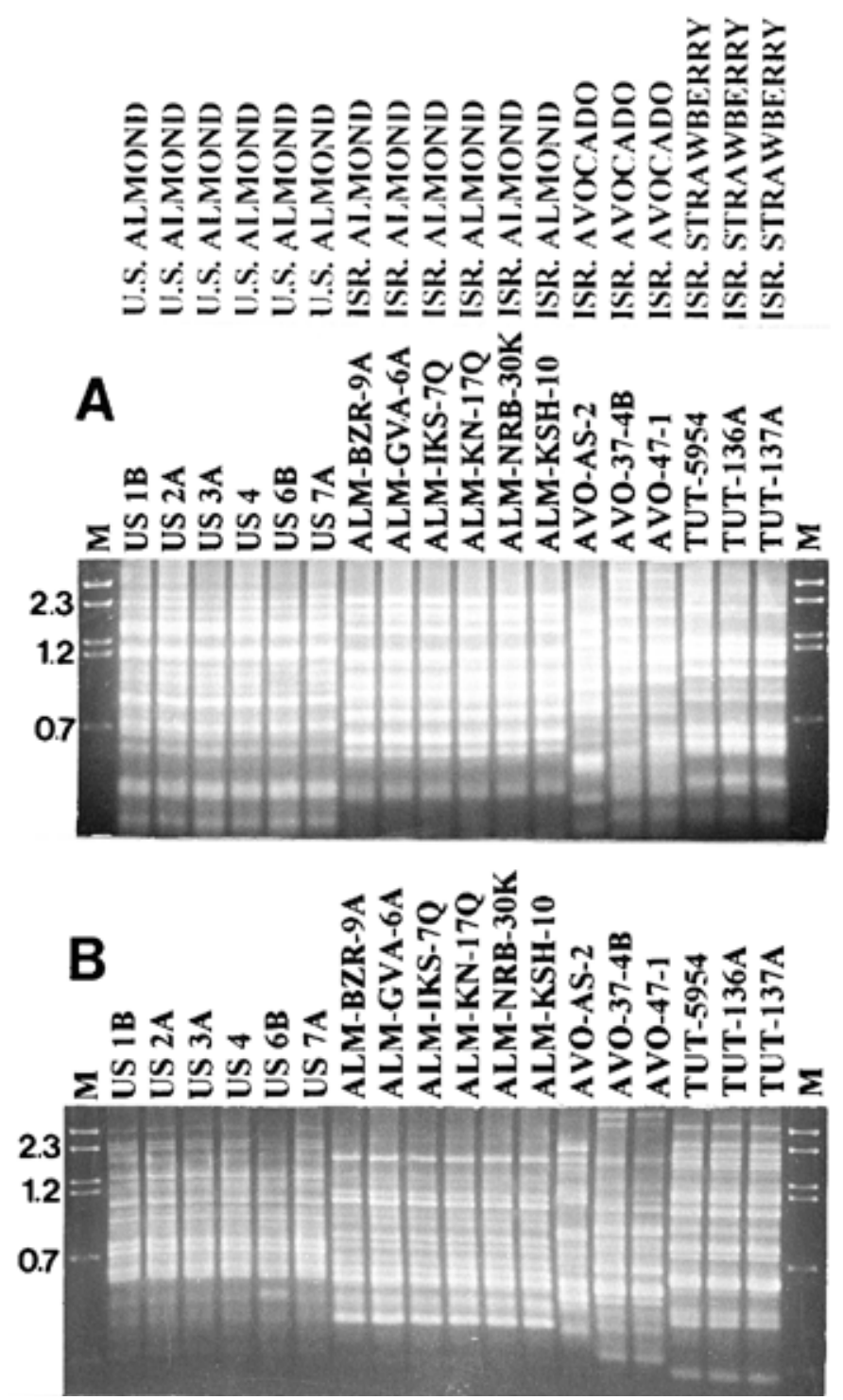

Fig. 2. Band patterns of arbitrarily primed polymerase chain reaction-amplified genomic DNA from U.S. Colletotrichum acutatum isolates from almond (ALM-US-1B, ALM-US-2A, ALM-US-3A ALM-US-4, ALM-US-6B, and ALM-US-7A), Israeli Colletotrichum isolates from almond (ALM-BZR-9A, ALM-GVA-6A, ALM-IKS-7Q, ALM-KN-17Q, ALM-NRB-30K, and ALM$\mathrm{KSH}-10$ ), Israeli $C$. gloeosporioides isolates from avocado (AVO-AS-2, AVO-37-4B, and AVO-47-1), and Israeli C. acutatum isolates from strawberry (TUT-5954, TUT-136A, and TUT-137A) using primers A, (CAG) $)_{5}$ and $\mathbf{B},(\mathrm{GACAC})_{3}$. Lane M: DNA markers with sizes in kilobases.
The $C a$ Int2-specific primer for $C$. acutatum in conjunction with the ITS 4 primer amplified a 490-bp fragment from genomic DNA of the U.S. and Israeli almond isolates, as well as the C. acutatum strawberry isolates, but not from DNA of the $C$. gloeosporioides avocado isolates (Fig. 1A). In contrast, DNA of the U.S. C. acutatum and Israeli almond isolates, as well as the $C$. acutatum strawberry isolates, were not amplified by the $C$. gloeosporioides-specific $C g$ Int primer in conjunction with the ITS 4 primer, whereas a 450-bp fragment was amplified from DNA of the C. gloeosporioides avocado isolates alone (Fig. 1B). Due to uncertainty regarding apparent morphological and molecular identities of the Israeli almond population, we have decided for convenience to refer to this population as Israeli Colletotrichum isolates from almond, without reference to species.

ap-PCR analysis. Genomic DNA from all isolates included in the taxon-specific analysis were amplified by ap-PCR using primers $(\mathrm{CAG})_{5},(\mathrm{GACAC})_{3},(\mathrm{TGTC})_{4}$, and (GACA) $)_{4}$ (Fig. 2). Amplified products from U.S. almond, Israeli almond, and Israeli strawberry isolates were identical among isolates within each population, indicating clonality, whereas heterogeneity was observed within the avocado population according to diversity of the amplified products. The same representative isolates that were used in the taxonspecific analysis were also used for ap-PCR. Identical banding patterns were produced with DNA of isolates within each population of the U.S. C. acutatum isolates from almond, Israeli Colletotrichum isolates from almond, and Israeli C. acutatum isolates from strawberry when amplified with primers $(\mathrm{CAG})_{5}$ and $(\mathrm{GACAC})_{3}$ (Fig. $2 \mathrm{~A}$ and $\mathrm{B}$, respectively) and with primers (TGTC) $)_{4}$ and

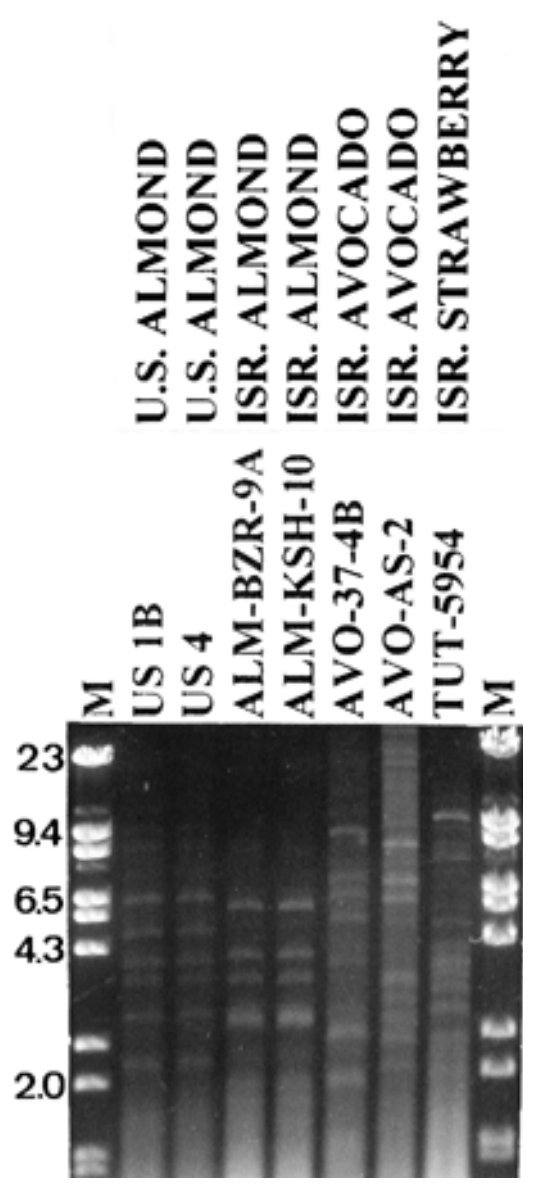

Fig. 3. Band patterns of genomic DNA from U.S. Colletotrichum acutatum isolates from almond (ALM-US-1B and ALM-US-4), Israeli Colletotrichum isolates from almond (ALM-BZR-9A and ALM-KSH-10), an Israeli C. gloeosporioides isolate from avocado (AVO-37-4B), and an Israeli C. acutatum isolate from strawberry (TUT-5954), digested with HaeIII for A+T-rich DNA analysis. DNA was electrophoresed until the major $\mathrm{G}+\mathrm{C}$-rich fragments were eluted from the gel. Lane M: DNA markers with sizes in kilobases. 
$(\text { GACA })_{4}$ (data not shown). No identity was observed between the different populations, namely, Israeli Colletotrichum almond isolates, U.S. C. acutatum almond isolates, C. acutatum strawberry isolates, and C. gloeosporioides avocado isolates (Fig. 2).

A+T-rich DNA analysis. A+T-rich DNA was analyzed by observing HaeIII digestions of genomic DNA from representative U.S. C. acutatum isolates (ALM-US-1B and ALM-US-4) and Israeli isolates (ALM-BZR-9A and ALM-KSH-10) from almond, $C$. gloeosporioides isolates from avocado (AVO-AS-2 and AVO-374B), and C. acutatum isolate TUT-5954 from strawberry (Fig. 3). Band patterns of two isolates from avocado (AVO-37-4B and AVOAS-2) were distinct from those of the almond isolates and that of strawberry. Ten additional avocado isolates had a different restriction fragment length polymorphism pattern compared with the above six avocado, almond, and strawberry isolates (data not shown). The populations of almond isolates from the United States and Israel each showed a unique, uniform band pattern indicating two distinct genotypes. The strawberry isolate was unique in its banding pattern. An additional 10 isolates from each population were analyzed by this method, with each being identical to the representative isolates of its population (data not shown).

Polymorphism of rDNA ITS 1 to ITS 2 restriction digests. Restriction endonuclease digest patterns of PCR-amplified rDNA ITS 1 to ITS 2 regions were compared for the representative U.S. C. acutatum isolates (ALM-US-1B, ALM-US-4, and ALM-US-6B) and Israeli Colletotrichum isolates (ALM-GVA-6A, ALM-KSH-10, and ALM-BZR-9A) from almond, C. gloeosporioides isolate AVO37-4B from avocado, and C. acutatum isolate TUT-5954 from strawberry. The enzyme RsaI distinguished between the representative isolates of Colletotrichum spp. (Fig. 4) by recognizing unique restriction sites, in contrast to the enzymes BamHI, HaeIII, HhaI, HindIII, MspI, PstI, StuI, and TaqI that did not possess unique sites among the different species. RsaI cleaved the amplified fragment of the U.S. almond isolates at a single site, whereas the fragment of the Israeli almond and strawberry isolates remained uncut

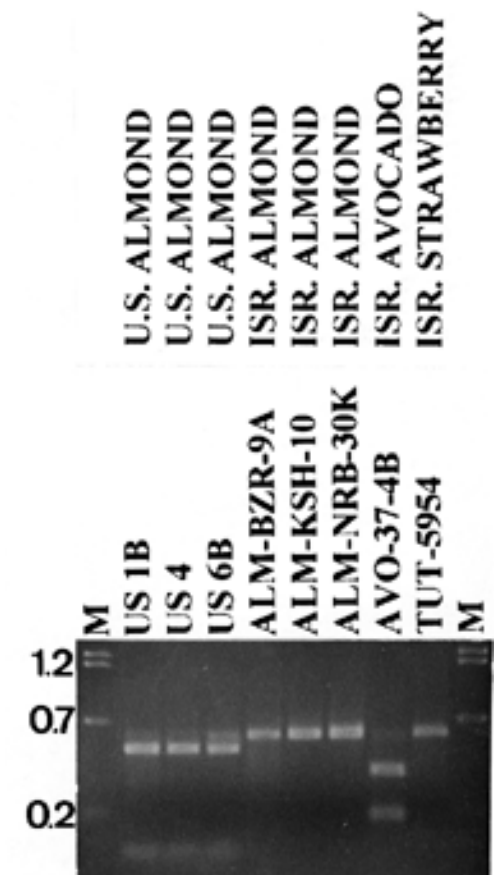

Fig. 4. RsaI restriction enzyme digests of polymerase chain reaction-amplified ribosomal DNA of the entire internal transcribed spacer (ITS) region (ITS 15.8S-ITS 2) from U.S. Colletotrichum acutatum isolates from almond (ALMUS-1B, ALM-US-4, and ALM-US-6B), Israeli Colletotrichum isolates from almond (ALM-BZR-9A, ALM-KSH-10, and ALM-NRB-30K), an Israeli $C$. gloeosporioides isolate from avocado (AVO-37-4B), and an Israeli $C$. $a c u$ tatum isolate from strawberry (TUT-5954). Lane M: DNA markers with sizes in kilobases.
(Fig. 4). The C. gloeosporioides isolate AVO-37-4B from avocado had a unique digestion pattern. An additional 10 isolates from each population were analyzed by this method, with each producing an identical pattern to that of the representative isolates (data not shown).

Sequence and phylogenetic analysis. The U.S. C. acutatum almond isolates were uniform in sequence; therefore, further analysis was conducted using representative isolate ALM-US-4. Similarly, the Israeli almond isolates were uniform; therefore, isolate ALM-KSH-10 was used for further analysis.

Phylogenetic analysis was performed using both the ITS 1 sequence (Fig. 5) and that of the ITS 1 to ITS 2 fragment (Table 3). Comparative analysis of ITS 1 sequences produced a phylogenetic tree (Fig. 5) that supported the previous analysis published by Sreenivasaprasad et al. (24). This analysis confirmed grouping of the Israeli strawberry isolate TUT-5954 in a clade with U.S. C. acutatum strawberry isolates 179 and 397 and the U.S. C. acutatum almond isolate ALM-US-4. Isolate ALM-US-4 was found to be closely related to isolate 179. Isolate ALM-KSH-10, previously identified as C. gloeosporioides (22; P. F. Cannon, personal communication), grouped together with $C$. acutatum isolate 534 from a Ceanothus sp. and isolate 602 from a Phormium sp. (24). Israeli C. gloeosporioides isolate AVO-37-4B from avocado grouped with $C$. gloeosporioides isolate 498 from Ziziphus jujuba and isolate 503 from Malus domestica.

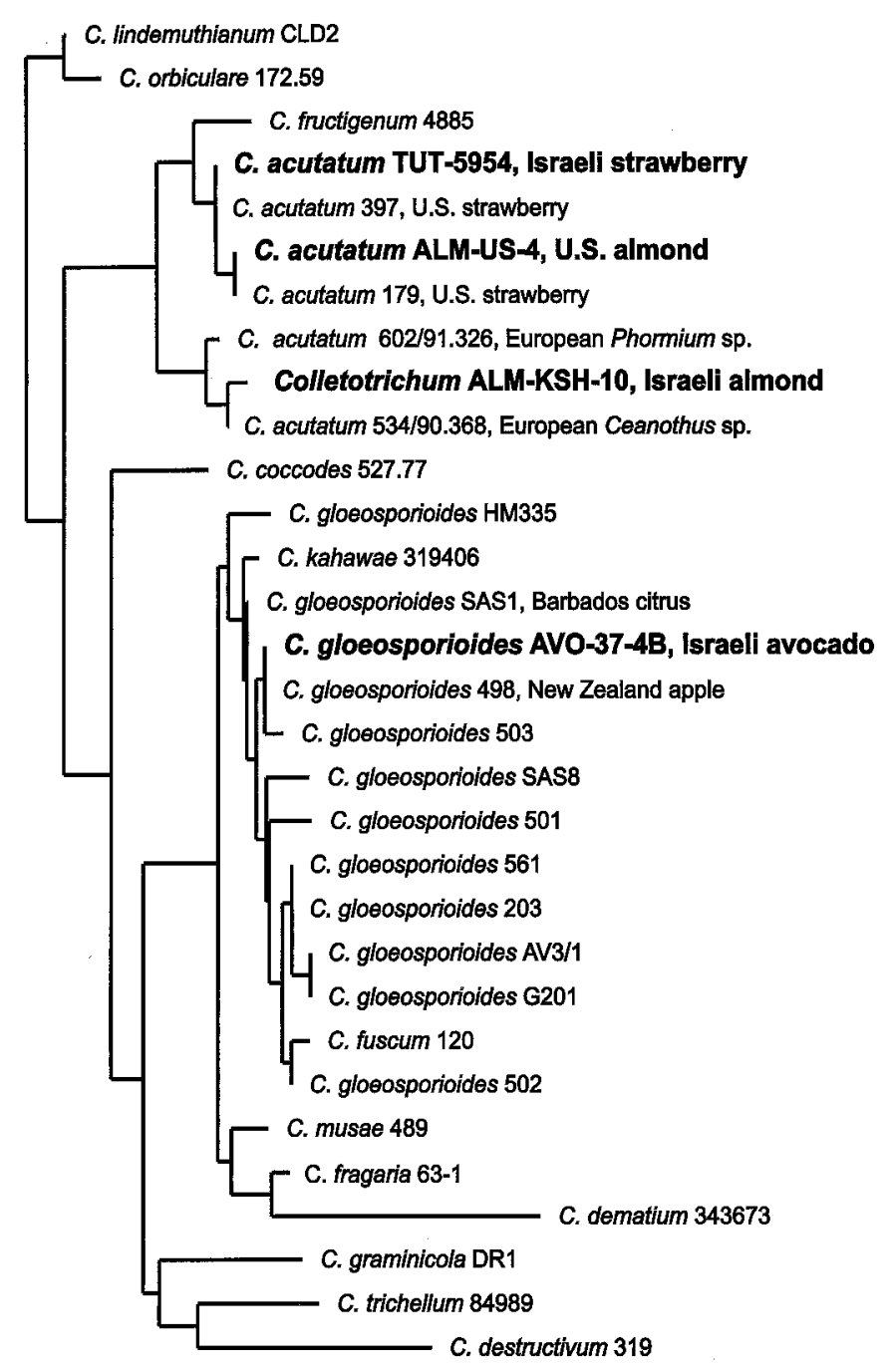

Fig. 5. Internal transcribed spacer 1-based phylogenetic tree of Colletotrichum isolates and published sequences. The tree was produced using the neighborjoining algorithm. The orders of branching was similar in all tree construction approaches used. Scale bar indicates estimated $10 \%$ sequence divergence 
Analysis of sequences of the ITS 1 to ITS 2 fragment supported the phylogeny inferred from the ITS 1 tree. The analysis was performed on the sequences of five isolates from which this sequence was available (C. acutatum isolate TUT-5954 from strawberry in Israel, $C$. acutatum isolate ALM-US-4 from the pink subpopulation of almond in the United States; Colletotrichum isolate ALM$\mathrm{KSH}-10$ from almond in Israel; C. gloeosporioides isolate AVO37-4B from avocado in Israel, as described in this study; and $C$. graminicola isolate DR1 [EMBL accession no. AF059676]). Sequence analysis of the ITS 1 to ITS 2 regions revealed a similarity of between 97.03 to $98.72 \%$ among the $C$. acutatum isolates from almond and strawberry and the Israeli isolates from almond (Table 3 ). Similarity of the above populations to that of C. gloeosporioides of avocado was between 92.42 to $92.86 \%$. The $C$. graminicola isolate DR1 was more closely related to the $C$. gloeosporioides cluster $(95.11 \%$ similar) than that of the $C$. acutatum populations (92.4 to $92.64 \%$ similar) (Table 3 ).

\section{DISCUSSION}

The main objective of this study was to determine whether the various molecular methods used in this study were consistent with morphotaxonomic criteria for delimiting species of the genus Colletotrichum. Of particular interest were the almond populations of Colletotrichum, C. acutatum from the United States and that from Israel. Using ap-PCR and A+T-rich, we were able to differentiate between the different populations' DNA at the subspecies level. The taxon-specific primers and ITS sequence analysis were useful for grouping the isolates according to species. However, the molecular analyses of species identification were not in strict accordance to morphotaxonomic characteristics.

Previous nonmolecular studies have distinguished between the almond pathogens, $C$. acutatum pink subpopulation from the United States, and the population from Israel (10). It was shown that the optimal growth temperature, average growth rate, and morphology in culture varied significantly for each population. In addition, each population had a single unique vegetative compatibility group. Moreover, each of the almond populations was clearly distinguished from the $C$. gloeosporioides avocado pathogen according to the above and additional criteria, such as presence of the teleomorph, fungicide sensitivity, and infection process. Recently, an additional $C$. acutatum gray subpopulation was reported from California, and this subpopulation is apparently similar to the Israeli almond pathogen according to molecular analyses (7). However, the morphological differences between these two populations still need to be addressed.

Each molecular method was evaluated for the ability to assess isolates within or between species. Assessment of intraspecies variation relied on ap-PCR and A+T-rich DNA analyses, each of which gave a single pattern for all Israeli Colletotrichum almond isolates (Figs. 2 and 3). This may be indicative of a clonal population of the almond pathogen that has probably spread throughout Israel. Similarly, by these methods, the U.S. pink subpopulation of $C$. acutatum almond isolates appeared uniform and unique, but different from the Israeli $C$. acutatum strawberry isolates and the Israeli population of almond isolates. Likewise, the $C$. acutatum strawberry population was homogeneous and apparently clonal
(Fig. 2). In contrast, ap-PCR and A+T-rich DNA analyses indicated multiple genotypes within the $C$. gloeosporioides avocado population, as previously described (9).

Due to its high rate of genetic variation, the ITS 1 region, ranging from 170 to $181 \mathrm{bp}$ within the rDNA gene cluster, is considered suitable for species delimitation (24). In this study, the complete 560-bp rDNA region, encompassing the ITS 1 to ITS 2 regions and the 5.8S rDNA gene, was used for DNA sequence analysis for a more comprehensive analysis. Sequence analysis of this ITS 1 to ITS 2 fragment supported the phylogeny inferred from the ITS 1 tree (Fig. 5). The analysis was performed on five isolates from which this sequence was available ( $C$. acutatum strawberry isolate TUT-5954 from Israel, C. acutatum almond isolate ALM-US-4 from the United States belonging to the pink subpopulation, Colletotrichum almond isolate ALM-KSH-10 from Israel, $C$. gloeosporioides avocado isolate AVO-37-4B from Israel described here, and $C$. graminicola isolate DR1 [EMBL accession no. AF059676]).

Phylogenetic analysis of the ITS 1 region confirmed that the Israeli strawberry isolate TUT-5954 clusters within the $C$. acutatum species, within a clade consisting of isolates 179, 397, 534, and 602, the U.S. C. acutatum almond isolate ALM-US-4, and the Israeli Colletotrichum almond isolate ALM-KSH-10 (Fig. 5). Analysis of the sequence data for the RsaI restriction site further indicated that variation exists within the $C$. acutatum species cluster. The $C$. gloeosporioides isolate of avocado from Israel clustered with C. gloeosporioides isolates 503 and 498, and possessed a unique $R s a$ I cleavage site that differed from isolates of the C. acutatum species (Fig. 4).

The phylogenetic grouping based on sequence data did not appear to be congruent with conidial morphology. For example, it has previously been shown that straight cylindrical conidial species, such as $C$. fragaria and $C$. gloeosporioides, clustered in the same group as those of $C$. capsici, which possess falcate conidia (24). Therefore, although conidial morphology is one of the important criteria for species delimitation, its reliability as the sole basis for this purpose is questionable, due to the possibility of intermediate shapes and sizes of conidia being present within a given, even clonal, population. This appears to be the case for the almond population from Israel that was identified previously as $C$. gloeosporioides (22), although some isolates exhibited conidial morphology and culture characteristics that were intermediate between $C$. gloeosporioides and C. acutatum (P. F. Cannon, personal communication). However, based on ITS sequence data, this population grouped within the $C$. acutatum species cluster. It is possible, therefore, that the morphological characteristics of the Israeli almond population are as yet ill defined and in a state of flux, despite the fact that it is considered a clonal population according to molecular analyses. This is in contrast to the U.S. pink subpopulation from almond, which conforms with the morphotaxonomic criteria of the species C. acutatum.

\section{ACKNOWLEDGMENTS}

Contribution from the Agricultural Research Organization, The Volcani Center, Bet Dagan, Israel, No. 506-99. This research was supported, in part, by Research Grant Award No. IS 2825-97 from BARD, The

TABLE 3. Percent similarity, according to nucleotide sequence distance among representative Colletotrichum isolates, was based on the entire internal transcribed spacer (ITS) region (ITS 1-5.8S-ITS 2) ${ }^{\mathrm{a}}$

\begin{tabular}{lcccc}
\hline Species (isolate) & AVO-37-4B & TUT-5954 & ALM-US-4 & ALM-KSH-10 \\
\hline C. gloeosporioides (AVO-37-4B) & 100.00 & 92.84 & 92.86 & 92.42 \\
C. acutatum (TUT-5954) & & 100.00 & 98.72 & 97.03 \\
C. acutatum (ALM-US-4) & & & 100.00 & 97.6 \\
Colletotrichum (ALM-KSH-10) & & & 92.11 \\
C. graminicola (DR1) & & & 92.63 \\
\hline
\end{tabular}

${ }^{a}$ Percent similarity, based on pairwise analysis of isolates, was calculated using the ARB software (25). 
United States-Israel Binational Agricultural Research and Development Fund, awarded to S. Freeman. We thank B. Teviotdale, University of California, Davis, for providing biological material from the United States.

\section{LITERATURE CITED}

1. Adaskaveg, J. E., and Hartin, R. J. 1997. Characterization of Colletotrichum acutatum isolates causing anthracnose of almond and peach in California. Phytopathology 87:979-987.

2. Alahakoon, P. W., Brown, A. E., and Sreenivasaprasad, S. 1994. Crossinfection potential of genetic groups of Colletotrichum gloeosporioides on tropical fruits. Physiol. Mol. Plant Pathol. 44:93-103.

3. Bailey, J. A., and Jeger, M. J. 1992. Colletotrichum: Biology, Pathology and Control. CAB International, Wallingford, United Kingdom.

4. Bernstein, B., Zehr, E. I., Dean, R. A., and Shabi, E. 1995. Characteristics of Colletotrichum from peach, apple, pecan, and other hosts. Plant Dis. 79:478-482.

5. Brown, A. E., Sreenivasaprasad, S., and Timmer, L. W. 1996. Molecular characterization of slow-growing orange and Key lime anthracnose strains of Colletotrichum from citrus as C. acutatum. Phytopathology 86:523-527.

6. Buddie, A. G., Martinez-Culebras, P., Bridge, P. D., Garcia, M. D., Querol, A., Cannon, P. F., and Monte, E. 1999. Molecular characterization of Colletotrichum strains derived from strawberry. Mycol. Res. 103:385-394.

7. Förster, H., and Adaskaveg, J. E. 1999. Identification of subpopulations of Colletotrichum acutatum and epidemiology of almond anthracnose in California. Phytopathology 89:1056-1065.

8. Freeman, S., and Katan, T. 1997. Identification of Colletotrichum species responsible for anthracnose and root necrosis of strawberry in Israel. Phytopathology 87:516-521.

9. Freeman, S., Katan, T., and Shabi, E. 1996. Characterization of Colletotrichum gloeosporioides isolates from avocado and almond fruits with molecular and pathogenicity tests. Appl. Environ. Microbiol. 62:10141020.

10. Freeman, S., Katan, T., and Shabi, E. 1998. Characterization of Colletotrichum species responsible for anthracnose diseases of various fruits. Plant Dis. 82:596-605.

11. Freeman, S., Pham, M., and Rodriguez, R. J. 1993. Molecular genotyping of Colletotrichum species based on arbitrarily primed PCR, A+T-rich DNA, and nuclear DNA analyses. Exp. Mycol. 17:309-322.

12. Grossman, L. I., and Hudspeth, M. E. S. 1985. Fungal mitochondrial genomes. Pages 65-103 in: Gene Manipulations in Fungi. J. W. Bennet and L. L. Lazure, eds. Academic Press, New York.

13. Gupta, M., and Filner, P. 1991. Microsatellites amplify highly polymorphic DNA bands in SPAR of plant DNA. Abstr. 1705 in: Proceedings. Int. Soc. Plant Mol. Biol., Tucson, AZ.

14. Howard, C. M., Maas, J. L., Chandler, C. K., and Albregts, E. E. 1992.
Anthracnose of strawberry caused by the Colletotrichum complex in Florida. Plant Dis. 76:976-981.

15. Johnston, P. R., and Jones, D. 1997. Relationships among Colletotrichum isolates from fruit-rots assessed using rDNA sequences. Mycologia 89:420-430.

16. Katan, T., and Shabi, E. 1996. Vegetative compatibility among isolates of Colletotrichum gloeosporioides from almond in Israel. Eur. J. Plant Pathol. 102:597-600.

17. Liyanage, H. D., McMillan, Jr., R. T., and Kistler, H. C. 1992. Two genetically distinct populations of Colletotrichum gloeosporioides from citrus. Phytopathology 82:1371-1376.

18. Munaut, F., Hamaide, N., Vander Stappen, J., and Maraite, H. 1998. Genetic relationships among isolates of Colletotrichum gloeosporioides from Stylosanthes spp. in Africa and Australia using RAPD and ribosomal DNA markers. Plant Pathol. 47:641-648.

19. Prusky, D., and Keen, N. T. 1993. Involvement of preformed antifungal compounds in the resistance of subtropical fruits to fungal decay. Plant Dis. 77:114-119.

20. Rodriguez, R. J., and Yoder, O. C. 1991. A family of conserved repetitive DNA elements from the fungal plant pathogen Glomerella cingulata (Colletotrichum lindemuthianum). Exp. Mycol. 15:232-242.

21. Sambrook, J., Fritsch, E. F., and Maniatis, T. 1989. Molecular Cloning: A Laboratory Manual. 2nd ed. Cold Spring Harbor Laboratory Press, Cold Spring Harbor, NY.

22. Shabi, E., and Katan, T. 1983. Occurrence and control of anthracnose of almond in Israel. Plant Dis. 67:1364-1366.

23. Sherriff, C., Whelan, M. J., Arnold, G. M., Lafay, J.-F., Brygoo, Y., and Bailey, J. A. 1994. Ribosomal DNA sequence analysis reveals new species groupings in the genus Colletotrichum. Exp. Mycol. 18:121-138

24. Sreenivasaprasad, S., Mills, P. R., Meehan, B. M., and Brown, A. E. 1996. Phylogeny and systematics of 18 Colletotrichum species based on ribosomal DNA spacer sequences. Genome 39:499-512.

25. Strunk, O., Ludwig, W., Gross, O., Reichel, B., Stuckmann, N., May, M., Nonhoff, B., Lenke, M., Ginhart, T., Vilbig, A., and Westran, R. 1998. ARB - A software environment for sequence data. Technische Universität Munchen, Munich, Germany.

26. Tu, J. C. 1985. An improved Mathur's medium for growth, sporulation and germination of spores of Colletotrichum lindemuthianum. Microbiosis 44:87-93.

27. Weising, K., Weigand, F., Driesel, A. J., Kahl, A. J., Zischer, H., and Epplen, J. T. 1989. Polymorphic simple GATA/GACA repeats in plant genomes. (Abstr.) Nucleic Acids Res. 17:10128.

28. White, T. J., Bruns, T., Lee, S., and Taylor, J. 1990. Amplification and direct sequencing of fungal ribosomal RNA genes for phylogenetics. Pages 315-322 in: PCR Protocols, A Guide to Methods and Applications. M. A. Innis, D. H. Gelfand, J. J. Sninsky, and T. J. White, eds. Academic Press, San Diego, CA. 